\title{
Methanosarcina semesiae sp. nov., a dimethylsulfide-utilizing methanogen from mangrove sediment
}

\author{
Thomas J. Lyimo, ${ }^{1,2}$ Arjan Pol, ${ }^{1}$ Huub J. M. Op den Camp, ${ }^{1}$ \\ Harry R. Harhangi ${ }^{1}$ and Godfried D. Vogels ${ }^{1}$
}
1 Department of Microbiology, Faculty of Science, University of Nijmegen, Toernooiveld 1, NL-6525 ED Nijmegen, The Netherlands
2 Microbiology Unit, Department of Botany, Faculty of Science, University of Dar es Salaam, PO Box 35060, Dar es Salaam, Tanzania

\author{
Author for correspondence: Huub J. M. Op den Camp. Tel: +31 24 652657. Fax: +31243652830 \\ e-mail: huubcamp@sci.kun.nl
}

\begin{abstract}
Methanosarcina semesiae $\mathrm{MD1}^{\top}{ }^{\top}(\mathrm{T}=$ type strain), a novel obligately methylotrophic methanogenic archaeon is described. Strain MD1 $^{\top}$ was isolated from an enrichment on dimethylsulfide inoculated with mangrove sediment. The cells were irregularly coccoid, non-motile, $1.4 \pm 0.2 \mu \mathrm{m}$ in diameter and stained Gram-positive. The catabolic substrates used included dimethylsulfide, methanethiol, methanol and methylated amines, but not acetate, formate, $\mathrm{H}_{2} / \mathrm{CO}_{2}$ or a combination of these substrates. When cells grown on dimethylsulfide were transferred to trimethylamine or methanol and vice versa, a lag phase was observed. The same lag phase occurred when cells grown on trimethylamine were transferred to methanol and vice versa, indicating that for each substrate different enzymes were induced. Fastest growth occurred within a temperature range of 30-35 ${ }^{\circ} \mathrm{C}$ and a pH of 6.5-7.5. Both $\mathrm{Na}^{+}$and $\mathrm{Mg}^{2+}$ were required for growth, with maximum growth rates at 200-600 $\mathrm{mM} \mathrm{Na}^{+}$and 20-100 $\mathrm{mM} \mathrm{Mg}{ }^{2+}$. The cells exhibited specific growth rates $\left(h^{-1}\right)$ of $0.07 \pm 0.02,0.15 \pm 0.04$ and $0.18 \pm 0.05$ on dimethylsulfide, methanol and trimethylamine, respectively. Analysis of the 165 rRNA gene sequence showed that strain $\mathrm{MD1}^{\mathrm{T}}$ was phylogenetically closely related to members of the genus Methanosarcina, but clearly differed from all described species of this genus (94-97\% sequence similarity).
\end{abstract}

Keywords: Methanosarcina semesiae sp. nov., archaea, methanogen, mangrove, dimethylsulfide

\section{INTRODUCTION}

Mangroves are characteristic of tropical coasts and are counterparts of tidal salt marshes of the temperate regions. An important characteristic of this ecosystem is that the sediment is anaerobic and highly reduced. Sulfate reduction and methanogenesis are the predominant terminal processes in the anaerobic degradation of organic matter in such environments. In marine sediment, where sulfate is readily available, sulfate reduction predominates (Crill \& Martens,

Abbreviations: COS, carbonylsulfide; DMA, dimethylamine; DMS, dimethylsulfide; MMA, monomethylamine; MT, methanethiol; TMA, trimethylamine.

The GenBank/EMBL accession number for the sequence of the $16 \mathrm{~S}$ rRNA gene of strain $\mathrm{MD1}^{\top}$ is $\mathrm{AJ} 012742$.
1986; Holmer \& Kristensen, 1994). However, methanogenesis co-exists in these environments, presumably by utilization of non-competitive substrates. Indeed, many methanogens isolated from marine sediments are obligately methylotrophic (Franklin et al., 1988; Kadam et al., 1994; Mohanraju et al., 1997; $\mathrm{Ni}$ et al., 1994; Oremland \& Boone, 1994). The inability of these obligate methylotrophic methanogens to use hydrogen or acetate shows that they occupy niches in which there is no competition for methylated substrates like dimethylsulfide (DMS), methanethiol (MT), trimethylamine (TMA) and methanol (Oremland \& Polcin, 1986; Oremland et al., 1982).

Volatile methylated sulfur compounds have been intensively studied since they play an important role in the global sulfur cycle. DMS and carbonylsulfide $(\mathrm{COS})$ constitute climatically relevant trace gases in 
the atmosphere (Andreae \& Raemdonck, 1983; Charlson et al., 1987). DMS has been estimated to account for half of the biogenic input of volatile sulfur into the atmosphere with nearly $75 \%$ of it being generated in marine regions (Andreae \& Raemdonck, 1983). The main precursor for DMS is dimethylsulfoniopropionate, an osmolyte of marine algae, phytoplankton, reef corals and some plants (Dacey \& Wakeham, 1986; Hill et al., 1995; Iverson et al., 1989; Paquet et al., 1995). Other precursors for DMS include methionine (Kiene \& Visscher, 1987) and methoxylated aromatic compounds, the latter in combination with inorganic sulfide (Bak et al., 1992; Kreft \& Schink, 1993).

Degradation of DMS and MT in anaerobic marine sediments has been ascribed to both sulfate-reducing bacteria and methanogenic archaea (Kiene, 1988; Kiene \& Capone, 1988; Kiene et al., 1986). Some obligately methylotrophic methanogens able to use DMS for growth and methanogenesis have been described: Methanohalophilus zhilinae WeN5 ${ }^{\mathrm{T}}$ (Mathrani et al., 1988); Methanohalophilus oregonensis WAL1 $^{\mathrm{T}}$ (Liu et al., 1990); Methanolobus bombayensis B-1 $1^{\mathrm{T}}$ (Kadam et al., 1994); and two strains of Methanosarcina siciliae, $\mathrm{T} 4 / \mathrm{M}^{\mathrm{T}}$ and $\mathrm{H} 1350$ (Ni \& Boone, 1991; $\mathrm{Ni}$ et al., 1994). Isolations of pure cultures of methanogens from mangrove sediment are scarce. Only recently, Mohanraju et al. (1997) isolated a methanogenic archaeon (Methanococcoides methylutens) which grew on TMA and methanol. DMS utilization was not tested and no phylogenetic analysis was made. In a previous study, we have shown that addition of DMS stimulated methanogenesis in a Tanzanian mangrove sediment (T. J. Lyimo and others, unpublished). The present paper reports the isolation and characterization of a novel DMS-consuming obligately methylotrophic methanogenic archaeon, Methanosarcina semesiae sp. nov. strain $\mathrm{MD}^{\mathrm{T}}(\mathrm{T}=$ strain $)$, from this sediment.

\section{METHODS}

Source of inoculum. Sediment samples were taken from the Mtoni creek mangrove forest, Dar es Salaam, Tanzania (bordering the Indian Ocean) located at approximately $6^{\circ}, 45^{\prime}$ latitude and $39^{\circ}, 41^{\prime}$ longitude. Annual rainfall in the region is about $1050 \mathrm{~mm}$. The major part of the area is muddy. Oceanic water covers the sediment surface from 0 to about 4 m depending on tidal variations and location (Lyimo et al., 1997). Samples were taken by pressing a sampler (plastic cylinder, $5 \cdot 5 \mathrm{~cm}$ i.d., $45 \mathrm{~cm}$ long) into the sediment. The sampler was tightly closed at both sides with airtight PVC plungers (3 cm high) and air was expelled through small openings in the plungers. The sampler was transported to the laboratory and opened in an anaerobic chamber.

Media and culture techniques. The sediment samples were diluted 2-3 times with anaerobic synthetic seawater $(\mathrm{NaCl}$, $460 \mathrm{mM} ; \mathrm{MgSO}_{4}, 40 \mathrm{mM} ; \mathrm{CaCl}_{2} .2 \mathrm{H}_{2} \mathrm{O}, 10 \mathrm{mM}$; and $\mathrm{KCl}$, $10 \mathrm{mM})$. The resulting slurries were dispensed into serum bottles and the headspace was gassed with $\mathrm{N}_{2} / \mathrm{CO}_{2}$. Ratios used for gassing of samples with $\mathrm{N}_{2} / \mathrm{CO}_{2}$ or $\mathrm{H}_{2} / \mathrm{CO}_{2}$ were
$80 \% / 20 \%(\mathrm{v} / \mathrm{v})$ at $0.5 \mathrm{~atm}$ overpressure. After several additions of low concentrations $(0.5 \mathrm{mM})$ of DMS, the enriched slurry was transferred to the modified mineral medium of Widdel \& Bak (1992). The medium contained the following compounds: $\mathrm{NaCl}, 340 \mathrm{mM}$; $\mathrm{NH}_{4} \mathrm{Cl}, 4.7 \mathrm{mM}$; $\mathrm{KH}_{2} \mathrm{PO}_{4}, 1.5 \mathrm{mM}$; $\mathrm{NaHCO}_{3}, 30 \mathrm{mM}$; KCl, $6.7 \mathrm{mM}$; $\mathrm{MgCl}_{2} .6 \mathrm{H}_{2} \mathrm{O}, 15 \mathrm{mM} ; \mathrm{CaCl}_{2} .2 \mathrm{H}_{2} \mathrm{O}, 1 \mathrm{mM} ; \mathrm{Na}_{2} \mathrm{~S}, 2 \mathrm{mM}$; $\mathrm{Na}_{2} \mathrm{~S}_{2} \mathrm{O}_{4}, 0 \cdot 2 \mathrm{mM} ; 1 \mathrm{ml}$ trace element solution $\mathrm{l}^{-1}$; and $10 \mathrm{ml}$ vitamin solution $\mathrm{1}^{-1}$. Trace element solution was made up of $\left(1^{-1}\right)$ : nitrilotriacetate, $15 \mathrm{~g} ; \quad \mathrm{FeSO}_{4} .7 \mathrm{H}_{2} \mathrm{O}, 1 \mathrm{~g} ; \mathrm{H}_{3} \mathrm{BO}_{3}$, $0.3 \mathrm{~g} ; \mathrm{H}_{2} \mathrm{SeO}_{3}, 0.12 \mathrm{~g} ; \mathrm{Al}_{2}\left(\mathrm{SO}_{4}\right)_{3} .12 \mathrm{H}_{2} \mathrm{O}, 0.32 \mathrm{~g} ; \mathrm{CuSO}_{4}$. $2 \mathrm{H}_{2} \mathrm{O}, 0.32 \mathrm{~g} ; \quad \mathrm{CoCl}_{2} .6 \mathrm{H}_{2} \mathrm{O}, 0.32 \mathrm{~g} ; \mathrm{Na}_{2} \mathrm{MoO}_{4} .2 \mathrm{H}_{2} \mathrm{O}$, $0.032 \mathrm{~g} ; \mathrm{NiCl}_{2} .6 \mathrm{H}_{2} \mathrm{O}, 0.31 \mathrm{~g} ; \mathrm{ZnSO}_{4} .7 \mathrm{H}_{2} \mathrm{O}, 0 \cdot 32 \mathrm{~g}$; and $\mathrm{MnCl}_{2} \cdot 4 \mathrm{H}_{2} \mathrm{O}, 0 \cdot 32 \mathrm{~g}$. Vitamin solution was made up of $\left(\mathrm{l}^{-1}\right)$ : p-aminobenzoic acid, $0.1 \mathrm{~g}$; riboflavin, $0.1 \mathrm{~g}$; thiamin, $0.2 \mathrm{~g}$; nicotinic acid, $0.2 \mathrm{~g}$; pyridoxine, $0.5 \mathrm{~g}$; pantothenic acid, $0.1 \mathrm{~g}$; cobalamin, $0.1 \mathrm{~g}$; biotin, $0.02 \mathrm{~g}$; folic acid, $0.05 \mathrm{~g}$; and lipoic acid, 0.05 g.

For substrate utilization experiments, anaerobic sterile stock solutions were added to the medium prior to inoculation. The substrates tested were: sodium acetate, $10 \mathrm{mM}$; DMS, $10 \mathrm{mM}$; MT, $5 \mathrm{mM}$; sodium formate, $20 \mathrm{mM}$; methanol, $20 \mathrm{mM}$; TMA/HCl, $10 \mathrm{mM}$; dimethylamine (DMA) $/ \mathrm{HCl}$, $10 \mathrm{mM}$; and monomethylamine (MMA)/HCl, $20 \mathrm{mM}$. Different $\mathrm{pH}$ values were obtained by adjusting the concentration of $\mathrm{NaHCO}_{3}$ (for $\mathrm{pH}$ range 5.5-7.0) and $\mathrm{Na}_{2} \mathrm{CO}_{3}$ (for $\mathrm{pH}$ range 7-9) or by use of HEPES $(25 \mathrm{mM}$ ). The $\mathrm{pH}$ changes (increase or decrease depending on substrate) during growth were $0.3 \mathrm{pH}$ units or less. Media with different $\mathrm{Na}^{+}$ values were obtained by adjusting $\mathrm{NaCl}$ concentration only (i.e. $\mathrm{NaHCO}_{3}, \mathrm{Ca}^{2+}$ and $\mathrm{Mg}^{2+}$ were kept constant). Media with various concentrations of $\mathrm{Mg}^{2+}$ and $\mathrm{Ca}^{2+}$ were prepared by adding sterile anoxic stock solutions to the prepared medium. When tested for $\mathrm{Mg}^{2+}, \mathrm{Ca}^{2+}$ was omitted and vice versa. The toxicity levels of DMS were tested by adding different concentrations (1-50 mM) of filter-sterilized DMS into sterile medium.

Enrichment and isolation. The DMS-utilizing methanogen was enriched by addition of low concentrations of DMS as the only catabolic substrate. However, after several transfers on DMS only, a combination of methanol (5 mM) and DMS (final concentration of $10 \mathrm{mM}$ ) was used. In this way, faster growth was obtained and the proportion of non-methanogenic contaminants decreased. Methanol was used because preliminary tests showed that DMS and methanol were used simultaneously. The enriched culture was serially diluted and inoculated into medium supplemented with $15 \mathrm{~g}$ purified agar $1^{-1}$ and $5 \mathrm{mM}$ DMS or a combination of $5 \mathrm{mM}$ methanol and $5 \mathrm{mM}$ DMS. From the agar tubes containing a few colonies, some colonies were picked with a hypodermic needle $(1 \cdot 1 \times 40 \mathrm{~mm})$ and purified by repeated dilution series in liquid medium supplemented with the same substrates. The purity of isolates was checked by addition of glucose $(1 \%, \mathrm{w} / \mathrm{v})$, yeast extract $(0 \cdot 2 \%, \mathrm{w} / \mathrm{v})$ and tryptic soy broth $(0 \cdot 2 \%, \mathrm{w} / \mathrm{v})$ which would result in growth of non-methanogenic contaminants. In addition, cultures were routinely examined with a phase-contrast microscope (Leitz Wetzlar).

Growth experiments. Optimum conditions for growth were determined by measuring specific growth rates under various conditions. Growth was quantified by measuring methane formation (growth rates calculated from optical density and methane formation during preliminary experiments were similar). The specific growth rates $(\mu)$ during exponential growth were calculated (linear regression) from plots in which the logarithm of total methane accumulated was 
plotted against time and expressed as $\mathrm{h}^{-1}$ (Powell, 1983). When the effects of environmental parameters $(\mathrm{pH}$, temperature, salt concentration) were tested, growth rates were determined from cultures adapted to those conditions. Cultures were transferred at least twice under the conditions tested before growth rates were measured.

When tested for utilization of acetate, formate and $\mathrm{H}_{2} / \mathrm{CO}_{2}$ (substrates which did not support growth), inocula were pregrown on different substrates (DMS, methanol and TMA). Cells were transferred at the exponential phase and incubated at $30^{\circ} \mathrm{C}$ for a month. Combinations of substrates were also tested (Muller et al., 1986; Boone \& Whitman, 1988). All incubations were performed at $30^{\circ} \mathrm{C}$ and $\mathrm{pH} 7$ unless otherwise stated. Growth on methylotrophic substrates was stimulated by yeast extract, but cultures were routinely grown in medium without yeast extract.

Analytical techniques. Methane formation was determined by GC using a Porapak Q (80/100 mesh) column and flameionization detection. In experiments with added methylated sulfur compounds, DMS, MT and $\mathrm{H}_{2} \mathrm{~S}$ were measured on a GC equipped with a flame photometric detector as described previously (Lomans et al., 1997).

16S rRNA gene analysis. For DNA extraction, cultures (3-6 ml) were centrifuged ( $2 \mathrm{~min}$ at $16000 \mathrm{~g}$ ), and the cells were lysed by resuspending the pellets in $550 \mu \mathrm{l}$ extraction buffer (Tris/ $\mathrm{HCl}, 10 \mathrm{mM}$; EDTA, $0.1 \mathrm{mM}$; and SDS, $0.5 \%)$. Proteinase $\mathrm{K}\left(100 \mu \mathrm{g} \mathrm{ml}^{-1}\right)$ was added, and the tubes were incubated at $65^{\circ} \mathrm{C}$ for $2-3 \mathrm{~h}$. Then, $900 \mu \mathrm{l}$ phenol:chloroform:isoamyl alcohol $(25: 24: 1)$ was added. After gentle mixing for 10 min the mixture was centrifuged $(16000 \mathrm{~g})$ for $10 \mathrm{~min}$. The top aqueous phase was transferred to a new sterile tube and extracted with chloroform:isoamyl alcohol (24:1). Then, $50 \mu \mathrm{l}$ sodium acetate $(3 \mathrm{M})$ and $1000 \mu \mathrm{l}$ ethanol $(96 \%)$ were added. The DNA was precipitated overnight at $-20{ }^{\circ} \mathrm{C}$ and collected by centrifugation $(10 \mathrm{~min}$ at $16000 \mathrm{~g}$ ). The pellet was washed with $250 \mu \mathrm{l}$ ethanol $(70 \%)$. After centrifugation, the pellets were air-dried for about $20 \mathrm{~min}$, dissolved in $50 \mu \mathrm{l}$ sterile demineralized water and stored at $-20^{\circ} \mathrm{C}$ until use.

The gene encoding the 16S rRNA was amplified by PCR with the archaea-specific primers REV007 (5'-GTTGATCCTGCCAGAGGYYA-3') and 23S047 (5'-CCCBGGGCTTATCGCAGCTT-3') (Raskin et al., 1994). Reaction mixtures contained the following components in a final volume of $50 \mu \mathrm{l}$ in a $200 \mu \mathrm{l}$ PCR reaction tube: $5 \mu 125 \mathrm{mM} \mathrm{MgCl}_{2}$; $5 \mu \mathrm{l} \mathrm{PCR}$ buffer $10 \times ; 2 \mu \mathrm{l} 5 \mathrm{mM}$ dNTP; $1 \mu \mathrm{l}$ Taq polymerase $\left(0.5\right.$ units $\left.\mu \mathrm{l}^{-1}\right) ; 31 \mu \mathrm{l}$ sterile $\mathrm{H}_{2} \mathrm{O} ; 2 \mu \mathrm{l}$ REV007 $\left(20 \mathrm{pmol}^{-1} \mathrm{l}^{-1}\right) ; 2 \mu \mathrm{l} 23 \mathrm{~S} 047\left(20 \mathrm{pmol} \mu \mathrm{l}^{-1}\right)$ and $2 \mu \mathrm{l}$ DNA template. The PCR was controlled with a thermocycler (Perkin Elmer) programmed as follows: denaturation at $94{ }^{\circ} \mathrm{C}$ for $4 \mathrm{~min}$, followed by 30 cycles consisting of denaturing at $94^{\circ} \mathrm{C}$ for $1 \mathrm{~min}$, annealing at $55^{\circ} \mathrm{C}$ for $1 \mathrm{~min}$ and extension at $72^{\circ} \mathrm{C}$ for $2 \mathrm{~min}$; the last cycle was followed by an additional extension at $72{ }^{\circ} \mathrm{C}$ for $10 \mathrm{~min}$ and cooling to $4{ }^{\circ} \mathrm{C}$. Amplified DNA fragments were separated by agarose gel electrophoresis (1\% agarose) and stained with ethidium bromide. The PCR fragment product was directly ligated into the pGEM-T easy vector according to the manufacturer's procedure (Promega). E. coli XL-1 Blue competent cells were used for transformation. Plasmid DNA of clones with an insert was isolated and purified using the FlexiPrep kit (Pharmacia). Sequencing of the 16S rRNA gene was performed on a Perkin Elmer automated laser fluorescent DNA sequencer (ABI 310) with the following primers: ARC1326 (5'-TGTGTGCAAGGAGCAGGGAC-3'); FOR1241 (5'-ACACGCGGGCTACAATG-3'); M13 REV and M13 FORW (pGEM-T easy vector primers); ARC915; MC1109; and REV344 and REV915 (Raskin et al., 1994) (REV344 and REV915 being the reverse of the sequences published).

Phylogenetic analysis. The $16 \mathrm{~S}$ rDNA sequence of strain $M D 1^{\mathrm{T}}$ was compared to sequences in the GenBank and EMBL databases using the BLAST algorithm (Dutch CAOS/ CAMM Center Facility, Nijmegen, The Netherlands). A selection of genera yielding the highest similarity was made and used to make an alignment with PILEUP (GCG package; Devereux et al., 1984). The alignment was checked manually and ambiguous positions were removed. Phylogenetic analysis was performed using the PHYLIP $3.5 \mathrm{c}$ package (Felsenstein, 1989). Bootstrap analysis was based on 100 resamplings of the dataset using the SEQBOOT program. The $16 \mathrm{~S}$ rRNA gene sequences of the archaea used in the tree have the following GenBank/EMBL accession numbers: Methanosaeta thermoacetophila CALS-1 (M59141), Methanosaeta concilii FE-INRA (M59146), Methanosaeta concilii Opfikon (X16932), Methanohalophilus oregonensis WAL1 ${ }^{\mathrm{T}}$ (U20152), Methanolobus taylorii GS-16 ${ }^{\mathrm{T}}$ (U20154), Methanolobus vulcani PL-12M ${ }^{\mathrm{T}}$ (U20155), Methanolobus bombayensis $\mathrm{B}-1^{\mathrm{T}}$ (U20148), Methanolobus tindarius Tindari3 ${ }^{\mathrm{T}}$ (M59135), Methanococcoides methylutens TMA-10 ${ }^{\mathrm{T}}$ (M59127), Methanococcoides burtonii DSM 6242 ${ }^{\mathrm{T}}$ (X65537), Methanohalophilus sp. SF1 (M59132), Methanohalophilus mahii SLP ${ }^{\mathrm{T}}$ (M59133), Methanohalobium evestigatum Z7303 ${ }^{\mathrm{T}}$ (U20149), Methanosarcina mazei SarPi (AF028691), Methanosarcina mazei S-6 ${ }^{\mathrm{T}}$ (U20151), Methanosarcina frisia $\mathrm{C} 16^{\mathrm{T}}$ (M59138), Methanosarcina thermophila $\mathrm{TM}-1^{\mathrm{T}}$ (M59140), Methanosarcina barkeri Sar (AF028692), Methanosarcina barkeri 227 (M59144), Methanosarcina acetivorans $\mathrm{C}_{2} \mathrm{~A}^{\mathrm{T}}$ (M59137), Methanosarcina siciliae $\mathrm{T} 4 / \mathrm{M}^{\mathrm{T}}$ (U20153), Methanosarcina sp. WH1 (M59136) and Methanospirillum hungateii JF1 (M60880).

\section{RESULTS AND DISCUSSION}

\section{Isolation}

Previously, it was clearly demonstrated that methanogens are involved in the degradation of DMS in mangrove sediments. The most probable numbers of methanogens from these sediments were also high, up to $10^{5}$ cells ( $\mathrm{g}$ fresh sediment) ${ }^{-1}$ (Lyimo et al., 1998). To obtain pure cultures of DMS-utilizing methanogens, micro-organisms were enriched by sequential additions of low amounts of DMS to mangrove sediment. The enrichment was serially diluted and inoculated in agar medium with DMS or DMS + methanol. A DMS utilizer, strain $\mathrm{MD}^{\mathrm{T}}$, was isolated from an agar tube with DMS as the only catabolic substrate. From the tubes with DMS + methanol, a second methanogenic strain was isolated, designated strain MM1. However, this strain was unable to utilize DMS. The $16 \mathrm{~S}$ rDNA sequence from cells of strain MM1 was compared to that from strain $\mathrm{MD}^{\mathrm{T}}$. Although they look morphologically identical, they were quite different phylogenetically. Strain MM1 was more closely related to Methanococcoides species whereas strain $\mathrm{MD}^{\mathrm{T}}$ was related to Methanosarcina species (see below). Strain MM1 has yet to be physiologically characterized. 
(a)

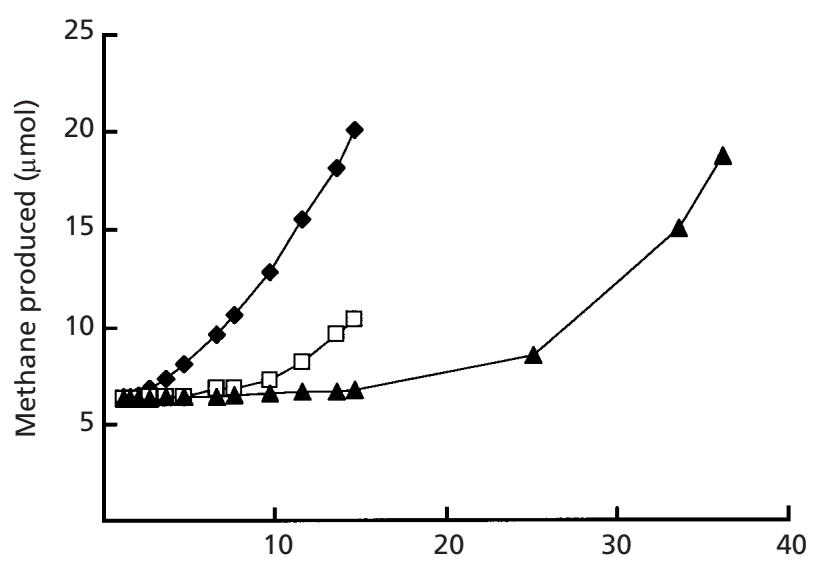

(b)

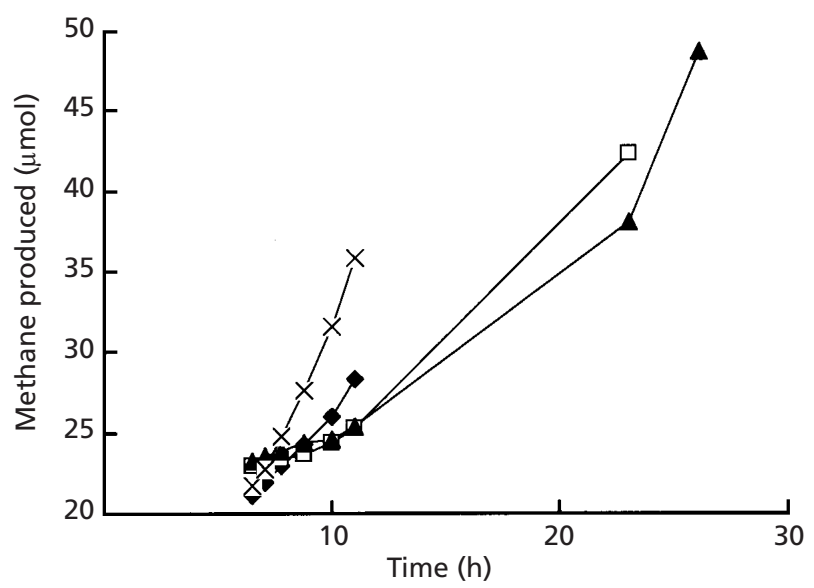

(c)

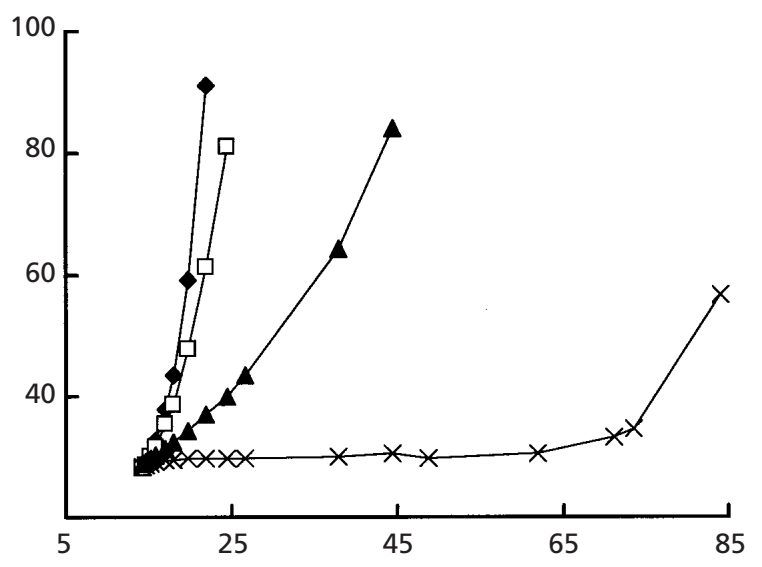

(d)

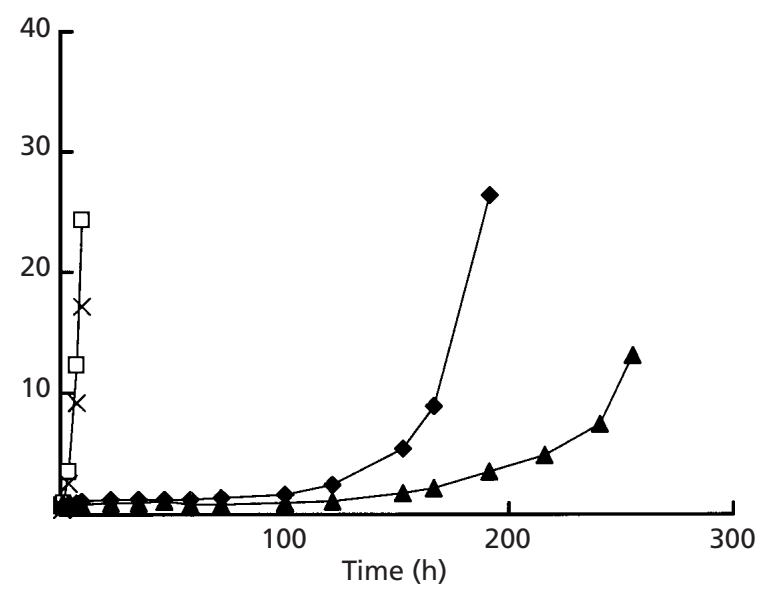

Fig. 1. Growth of strain $M D 1^{\top}$ after transfer from $D M S$, methanol or TMA-containing media to new media with different carbon sources. (a) Transfer of DMS-grown cells to DMS ( $\bullet$ ), methanol ( $\square$ ) or TMA ( $\mathbf{A})$. (b) Transfer of methanol-grown cells to methanol $(\times)$, MMA $(\boldsymbol{\Delta})$, DMA $(\square)$ or TMA $(\diamond)$. (c) Transfer of TMA-grown cells to TMA $(\diamond)$, DMA $(\square)$, MMA $(\boldsymbol{\Delta})$ or methanol $(x)$. (d) Transfer of methanol-grown cells to methanol $(\square)$ or DMS $(\diamond)$ and TMA-grown cells to TMA $(\times)$ or DMS ( $\mathbf{\Delta})$.

\section{Morphology}

Cells of strain $\mathrm{MD}^{\mathrm{T}}$ were single, non-motile and irregularly coccoid, with a diameter of $0 \cdot 8-2 \cdot 1 \mu \mathrm{m}$ with a mean of $1 \cdot 4 \pm 0 \cdot 2 \mu \mathrm{m} \quad(n=50$; determined from phase-contrast microphotographs). Aggregates were not found. Since the presence of flagella was not determined, the possibility of motility cannot be excluded. From microscopic observations, it was concluded that cells stained Gram-positive and lysed on addition of water or SDS (final concentration $2 \%$, $\mathrm{w} / \mathrm{v}$ ) indicating that a proteinaceous cell wall was present (Boone et al., 1993).

\section{Catabolic substrates}

Strain $\mathrm{MD}^{\mathrm{T}}$ was able to metabolize DMS, MT, methanol and methylated amines (MMA, DMA and TMA) since these substrates resulted in methane production and an increase in optical density of the cultures. Acetate, formate or $\mathrm{H}_{2} / \mathrm{CO}_{2}$ did not result in growth or in methane production. Cells also did not utilize a combination of acetate and hydrogen, not even in the presence of methanol. The isolated archaeon was tested for toxic levels of DMS. No growth or methane production was observed at DMS concentrations of $30 \mathrm{mM}$ or higher. In most cases, cells grew linearly when DMS concentrations above $20 \mathrm{mM}$ were used. During growth on DMS, the isolate produced significant amounts of MT (maximum $1.5 \mathrm{mM}$ ) as an intermediate; on MT, the isolate released small amount of DMS. This corresponds with published data on other DMS-utilizing methanogens (Finster et al., 1992; Ni \& Boone, 1991).

When cells adapted to DMS were transferred to methanol and TMA a lag phase of about $5 \mathrm{~h}$ and $15 \mathrm{~h}$, respectively, was observed (Fig. 1a). When cells adapted to methanol were transferred to methylated amines (MMA, DMA or TMA), the lag phase was about $2 \mathrm{~h}$ 
(a)

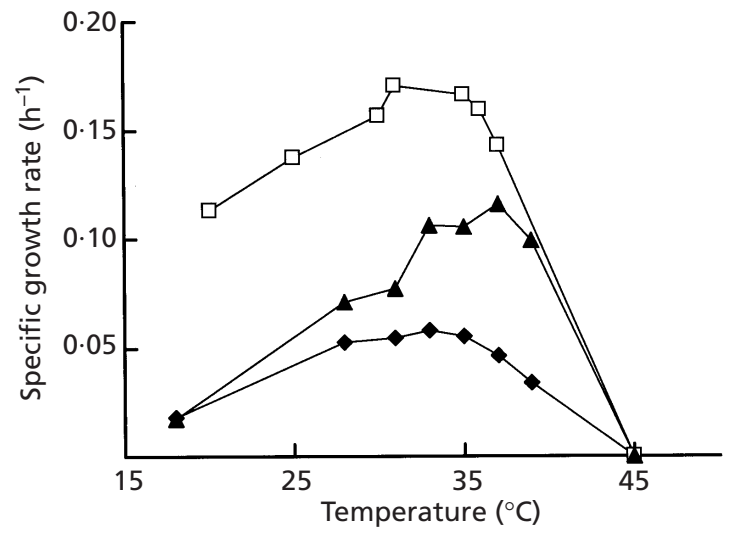

(b)

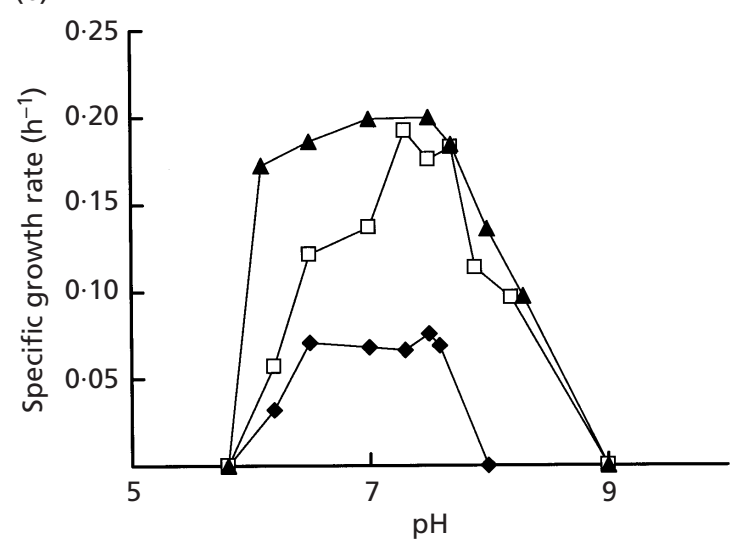

Fig. 2. Temperature optimum (a) and $\mathrm{pH}$ optimum (b) for growth of strain $\mathrm{MD}^{\top}{ }^{\top}$. The specific growth rate $(\mu)$, determined from the methane production rate during the exponential growth phase, is plotted against the incubation temperature (a) and $\mathrm{pH}$ (b). Growth was tested with different substrates: DMS $(\diamond)$, methanol $(\square)$ and TMA $(\boldsymbol{\Delta})$. Values are expressed in $\mathrm{h}^{-1}$ and are the means of two independent cultures.

(Fig. 1b). Cells grown on TMA had a much longer lag phase $(\sim 50 \mathrm{~h})$ before growth on methanol started whereas no lag phase was observed when the cells were transferred to DMA or MMA (Fig. 1c). TMA- and methanol-grown cells began to produce methane after a lag phase of 3-5 d when transferred to DMS (Fig. 1d). The ability to catabolize DMS was highly dependent on the growth phase of the methanol or TMA culture. The best results were obtained when cultures were transferred in the exponential phase. Cultures transferred at the late exponential or stationary phase were unable to utilize DMS even after incubation for 4 weeks. These results are in contrast with those showed by $\mathrm{Ni} \&$ Boone (1991) for Methanosarcina siciliae H1350. In this micro-organism, the enzymes for the utilization of methanol and TMA were constitutively expressed. Our results with strain $\mathrm{MD}^{\mathrm{T}}$ clearly demonstrate that the enzymes involved in DMS, methanol and TMA degradation are different and have to be induced.
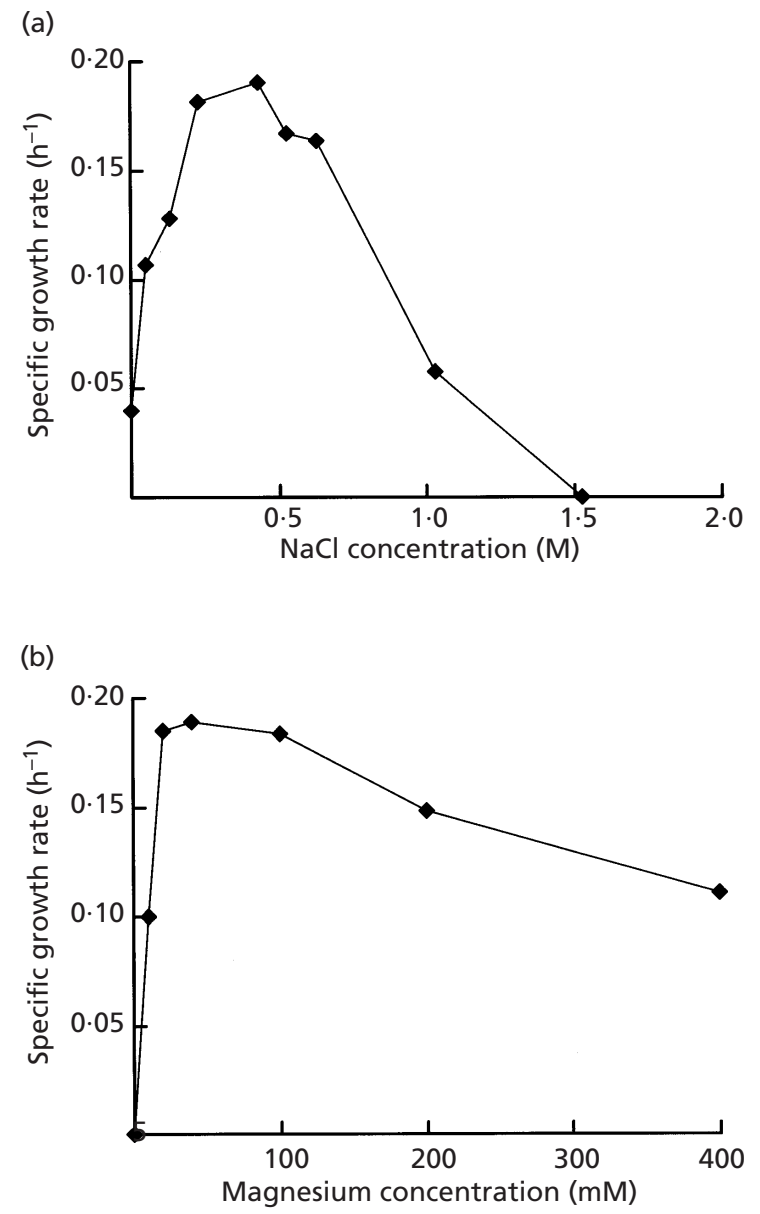

Fig. 3. $\mathrm{NaCl}$ range and magnesium requirement for growth of strain $\mathrm{MD}^{\top}$. The specific growth rate $(\mu)$, determined from the methane production rate during the exponential growth phase, is plotted against the $\mathrm{NaCl}$ concentration (a) and the initial $\mathrm{Mg}^{2+}$ concentration (b) in the medium. Values are expressed in $\mathrm{h}^{-1}$ and are the means of two independent cultures.

The methanogenic conversion of methanol and methylated amines proceeds by similar mechanisms (Wassenaar et al., 1996). Little information is available concerning biochemical pathways for methanogenesis from methylated thiols. Ni \& Boone (1993) published some initial experiments with cell-free extracts from Methanosarcina siciliae. Enzymes involved in the metabolism of DMS have not been identified from typical DMS-utilizing methanogens. Recently, Tallant \& Krzycki (1997) identified a $480 \mathrm{kDa}$ coenzyme Mmethylase from Methanosarcina barkeri MS, grown on acetate, as the only enzyme detectable which is capable of carrying out coenzyme $\mathrm{M}$ methylation from methylated thiols. However, they were unable to establish cultures of Methanosarcina barkeri MS with DMS as the sole substrate. Strain $\mathrm{MD}^{\mathrm{T}}$ is interesting for biochemical studies since it is relatively simple to handle and it has a reasonable growth rate on DMS (maximum growth rate $0.095 \mathrm{~h}^{-1}$ ). Thus, we hope to use this organism for biochemical studies in the near future. 


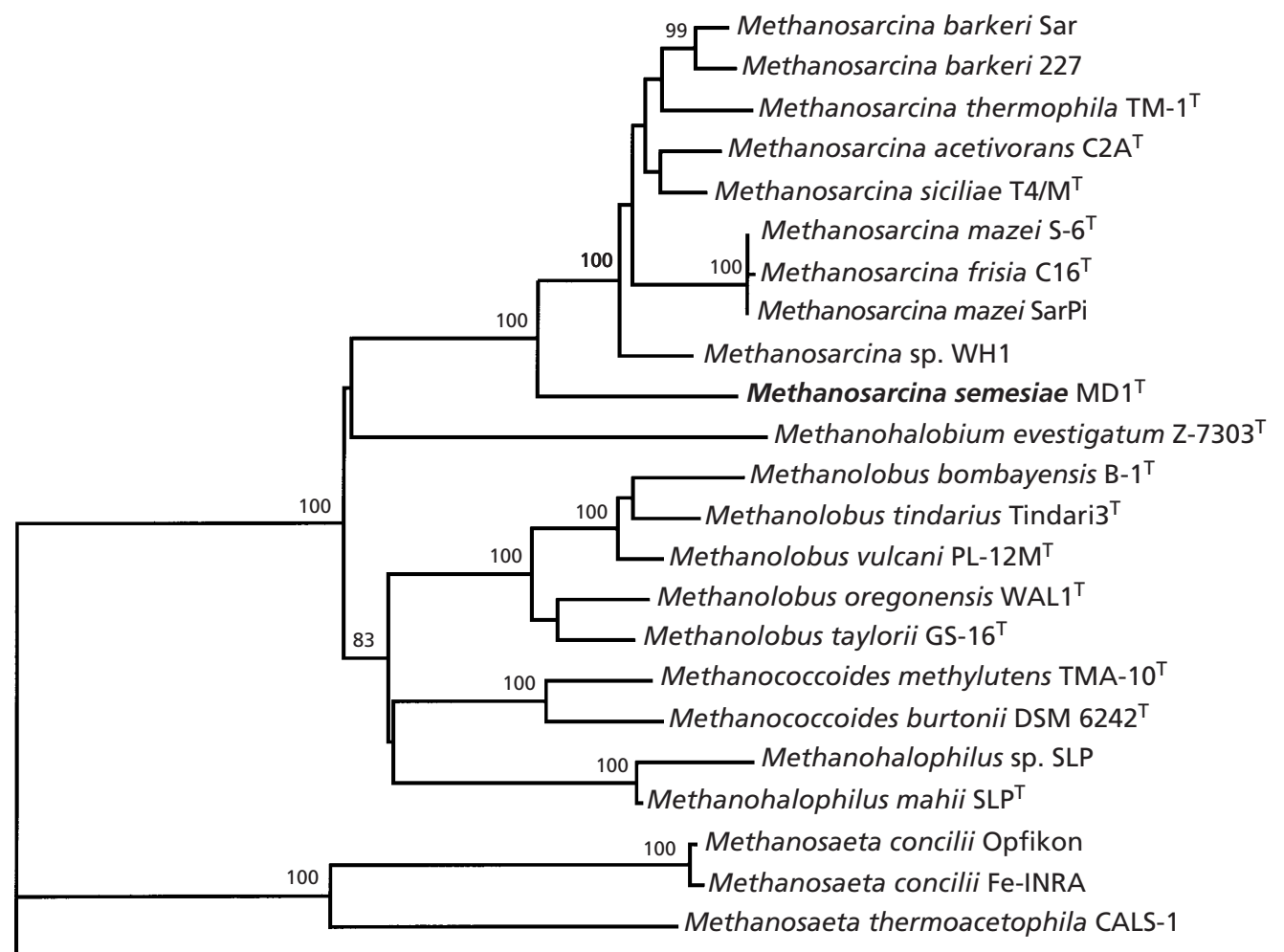

Methanospirillum hungateii JF1

$0 \cdot 1$

Fig. 4. A phylogenetic tree based on a distance matrix (EFITCH) calculated from 1288 unambiguously aligned positions of strain $\mathrm{MD}^{\top}{ }^{\top}$ and 23 other methanogens. Methanospirillum hungatei JF1 was defined as the outgroup. Bootstrap values are given to the left of a node; only values above 80 are given. Scale bar, the expected number of changes per sequence position along the horizontal lines of the tree.

\section{Optimum growth conditions}

Fig. 2 shows the influence of temperature and $\mathrm{pH}$ on growth and methanogenesis. Optimum growth took place within the temperature range $30-35^{\circ} \mathrm{C}$ and at $\mathrm{pH}$ values between 6.5 and $7 \cdot 5$. Cells were able to grow and produce methane at temperatures of $18-39{ }^{\circ} \mathrm{C}$ (lower temperatures were not tested) and a $\mathrm{pH}$ range of $6 \cdot 2-8 \cdot 3$ on methanol or TMA. On DMS, growth occurred within the same range of temperatures but no growth was found when the $\mathrm{pH}$ was above 8 . The mean specific growth rates $(\mu)$ under optimum conditions were $0 \cdot 07 \pm 0 \cdot 02,0 \cdot 15 \pm 0 \cdot 04$ and $0 \cdot 18 \pm 0 \cdot 05 \mathrm{~h}^{-1}(n=30$ for all values) on DMS, methanol and TMA, respectively.

Fastest growth occurred when the $\mathrm{NaCl}$ concentration was about 200-600 mM (Fig. 3a). Methane formation from cells inoculated into a medium without addition of $\mathrm{NaCl}$ (only $\mathrm{NaHCO}_{3}$ present) was linear and no growth was observed. The optimal $\mathrm{Mg}^{2+}$ concentration was $20-100 \mathrm{mM}$ (Fig. 3b). $\mathrm{Mg}^{2+}$ could be replaced by 5-10 $\mathrm{mM}$ of $\mathrm{Ca}^{2+}\left(\mathrm{Ca}^{2+}\right.$ concentrations $>10 \mathrm{mM}$ resulted in a precipitate). Methane formation from a culture without $\mathrm{Mg}^{2+}$ or $\mathrm{Ca}^{2+}$ was linear and cells lysed after $2 \mathrm{~d}$ incubation at $35^{\circ} \mathrm{C}$. Inocula for controls came from cultures grown with $1 \mathrm{mM} \mathrm{Ca}^{2+}$ and $15 \mathrm{mM}$ $\mathrm{Mg}^{2+}$. These results indicate that both $\mathrm{Na}^{+}$and either $\mathrm{Mg}^{2+}$ or $\mathrm{Ca}^{2+}$ were required for growth.

\section{S rRNA sequence characterization}

The 16S rDNA sequence data were obtained for positions 27-1478 (Methanosarcina barkeri numbering) of the 16S rRNA gene. When compared to other sequences the $16 \mathrm{~S}$ rRNA gene of strain $\mathrm{MD}^{\mathrm{T}}$ was found to be most similar to the sequences of Methanosarcina strains $(94 \cdot 7-96.0 \%)$. Highest similarity was observed with Methanosarcina siciliae. A phylogenetic tree based on a distance matrix (EFITCH) calculated from 1288 unambiguously aligned positions of strain $\mathrm{MD}^{\mathrm{T}}$ and 23 other methanogens is shown in Fig. 4. The topology of the tree was also checked with alternative methods (parsimony and bootstrap parsimony analysis). Strain $\mathrm{MD}^{\mathrm{T}}$ clusters within the family Methanosarcinaceae and appears to be most closely related to the genus Methanosarcina, although the position of strain $\mathrm{MD}^{\mathrm{T}}$ is always outside of the cluster of known representatives of this genus. Clustering is supported by high bootstrap values. Rouviere et al. (1992) defined a fully conserved signature sequence 
for the 'methanosarcina group' of the order Methanosarcinales, present in a helical region, at positions 234-242 and 248-256 (Methanosarcina barkeri numbering). Remarkably, in strain $M D 1^{\mathrm{T}}$ two bases in this region were different: $\mathrm{C}$ instead of $\mathrm{T}$ at position 237 and $\mathrm{G}$ instead of $\mathrm{A}$ at position 253.

\section{Taxonomy}

The physiological and morphological characteristics together with the phylogenetic analysis of the $16 \mathrm{~S}$ rRNA gene sequence of strain $M D 1^{\mathrm{T}}$ suggested that this organism is a member of the genus Methanosarcina. Like Methanosarcina species, strain $\mathrm{MD}^{\mathrm{T}}$ utilized DMS, methanol and methylated amines. On the basis of substrate utilization, strain $\mathrm{MD}^{\mathrm{T}}$ was most similar to Methanosarcina siciliae. However, morphologically these two strains differed; Methanosarcina siciliae forms massive aggregates with pseudosarcinae (Ni \& Boone, 1993; Ni et al., 1994) whereas strain $M D 1^{\mathrm{T}}$ occurs as single irregular coccoid cells. Furthermore, a strain of Methanosarcina siciliae (C2J) was reported to utilize acetate (Elberson \& Sowers, 1997) whereas strain MD1 ${ }^{\mathrm{T}}$ was an obligate methylotroph. Since our isolate was obtained from an enrichment with DMS as substrate, it is possible that we selected for an obligate methylotroph that has a mutation in the aceticlastic pathway. It cannot be excluded that enrichment on acetate would yield strains of this species which are not obligately methylotrophic. The observation that strain $\mathrm{MD} 1^{\mathrm{T}}$ occurred as single cells resembled the situation seen in some strains of Methanosarcina frisia and Methanosarcina mazei but these species are not restricted to methylotrophy (Blotevogel \& Fischer, 1989; Maestrojuán et al., 1992). The 16S rRNA gene sequence of strain MD1 ${ }^{\mathrm{T}}$ differed by $4 \cdot 0-5 \cdot 3 \%$ from all described species of the genus Methanosarcina. Phylogenetic analysis of the family Methanosarcinaceae based on 16S rRNA and $m c r 1$ gene sequences revealed intergeneric distance values of $97 \pm 0.65 \%$ and distance values of $92 \pm 1 \%$ between different genera of this family (Springer et al., 1995). In view of the above mentioned arguments, and supported by the deep phylogenetic division of this strain from other strains of Methanosarcina, it is proposed to include strain $\mathrm{MD}^{\mathrm{T}}$ in the genus Methanosarcina as a new species, Methanosarcina semesiae sp. nov.

\section{Description of Methanosarcina semesiae sp. nov.}

Methanosarcina semesiae (sem.es.i.ae. M.L. gen. n. semesiae of semesi, named after Adelaida K. Semesi in recognition of her many contributions to marine biology studies and for her mentorship/supervision of many postgraduate students in the field of microbiology).

Cells are coccoid bodies $1 \cdot 4 \pm 0 \cdot 2 \mu \mathrm{m}$ in diameter occurring as individual cells. Susceptible to hyposmotic lysis. Cells stain Gram-positive. Obligate meth- ylotroph. DMS, MT, methanol, MMA, DMA and TMA used for growth and methanogenesis. Acetate, formate and $\mathrm{H}_{2} / \mathrm{CO}_{2}$ are not utilized. The aforementioned substrate utilization, however, is based on only one strain. Cells grow optimally at $30-35{ }^{\circ} \mathrm{C}$, pH 6.5-7.5 and in the presence of $0.2-0.6 \mathrm{M} \mathrm{NaCl}$ and $10-100 \mathrm{mM} \mathrm{Mg}^{2+}$ or $5-10 \mathrm{mM} \mathrm{Ca}^{2+}$. Habitat is marine sediments. The type strain is $\mathrm{MD}^{\mathrm{T}}$, which was isolated from Indian Ocean sediments obtained from the mangrove forest at Mtoni creek, Dar es Salaam, Tanzania. M. semesiae strain MD ${ }^{\mathrm{T}}$ is deposited in the DSM culture collection (DSM 12914).

\section{ACKNOWLEDGEMENTS}

The PhD grant of T.J.L. was sponsored by the Directorate General for International Cooperation (DGIS), Ministry of Foreign Affairs of the Netherlands.

\section{REFERENCES}

Andreae, M. O. \& Raemdonck, H. (1983). Dimethyl sulfide in the surface ocean and the marine atmosphere: a global view. Science 221, 744-747.

Bak, F., Finster, K. \& Rothfuß, F. (1992). Formation of dimethylsulfide and methanethiol from methoxylated aromatic compounds and inorganic sulfide by newly isolated anaerobic bacteria. Arch Microbiol 157, 529-534.

Blotevogel, K. \& Fischer, U. (1989). Transfer of Methanococcus frisius to the genus Methanosarcina as Methanosarcina frisia comb. nov. Int J Syst Bacteriol 39, 91-92.

Boone, D. R. \& Whitman, W. B. (1988). Proposal of minimal standards for describing new taxa of methanogenic bacteria. Int J Syst Bacteriol 38, 212-219.

Boone, D. R., Whitman, W. B. \& Rouvière, P. (1993). Diversity and taxonomy of methanogens. In Methanogenesis, pp. 35-80. Edited by J. G. Ferry. New York: Chapman \& Hall.

Charlson, R. J., Lovelock, J. E., Andreae, M. O. \& Warren, S. G. (1987). Oceanic phytoplankton, atmospheric sulfur, cloud albedo and climate. Nature 326, 655-661.

Crill, P. M. \& Martens, C. S. (1986). Methane production from bicarbonate and acetate in an anoxic marine sediment. Geochim Cosmochim Acta 50, 2089-2097.

Dacey, J. W. H. \& Wakeham, S. G. (1986). Oceanic dimethylsulfide: production during zooplankton grazing on phytoplankton. Science 233, 1314-1316.

Devereux, J., Haeberli, P. \& Smithies, O. (1984). A comprehensive set of sequence analysis programs for the VAX. Nucleic Acids Res 12, 387-395.

Elberson, M. A. \& Sowers, K. R. (1997). Isolation of an aceticlastic strain of Methanosarcina siciliae from marine canyon sediments and emendation of the species description for Methanosarcina siciliae. Int $J$ Syst Bacteriol 47, 1258-1261.

Felsenstein, J. (1989). PHYLIP - Phylogeny Inference Package (version 3.2). Cladistics 5, 164-166.

Finster, K., Tanimoto, Y. \& Bak, F. (1992). Fermentation of methanethiol and dimethylsulfide by a newly isolated methanogenic bacterium. Arch Microbiol 157, 425-430.

Franklin, M. J., Wiebe, W. J. \& Whitman, W. B. (1988). Population of methanogenic bacteria in Georgia salt marsh. Appl Environ Microbiol 54, 1151-1157. 
Hill, R. W., Dacey, J. W. H. \& Krupp, D. A. (1995). Dimethylsulfoniopropionate in reef corals. Bull Mar Sci 57, 489-494.

Holmer, M. \& Kristensen, E. (1994). Coexistence of sulfate reduction and methane production in an organic-rich sediment. Mar Ecol Prog Ser 107, 177-184.

Iverson, R. L., Nearhoof, F. L. \& Andreae, M. O. (1989). Production of dimethylsulfoniumpropionate and dimethyl sulfide by phytoplankton in estuarine and coastal waters. Limnol Oceanogr 34, 53-67.

Kadam, P. C., Ranade, D. R., Mandelco, L. \& Boone, D. R. (1994). Isolation and characterization of Methanolobus bombayensis sp. nov., a methylotrophic methanogen that requires high concentrations of divalent cations. Int J Syst Bacteriol 44, 603-607.

Kiene, R. P. (1988). Dimethyl sulfide metabolism in salt marsh sediments. FEMS Microb Ecol 11, 71-78.

Kiene, R. P. \& Capone, D. G. (1988). Microbial transformations of methylated sulfur compounds in anoxic salt marsh sediments. Microb Ecol 15, 275-291.

Kiene, R. P. \& Visscher, P. T. (1987). Production and fate of methylated sulfur compounds from methionine and dimethylsulfoniopropionate in anoxic salt marsh sediments. Appl Environ Microbiol 53, 2426-2434.

Kiene, R. P., Oremland, R. S., Catena, A., Miller, L. W. \& Capone, D. G. (1986). Metabolism of reduced methylated sulfur compounds by anaerobic sediments and a pure culture of an estuarine methanogen. Appl Environ Microbiol 52, 1037-1045.

Kreft, J. U. \& Schink, B. (1993). Demethylation and degradation of phenylmethylethers by the sulfide-methylating homoacetogenic bacterium strain TMBS 4. Arch Microbiol 159, 308-315.

Liu, Y., Boone, D. R. \& Choy, C. (1990). Methanohalophilus oregonense sp. nov., a methylotrophic methanogen from an alkaline saline aquifer. Int $J$ Syst Bacteriol 40, 111-116.

Lomans, B. P., Smolders, A. J. P., Intven, L. M., Pol, A., Op den Camp, H. J. M. \& van der Drift, C. (1997). Formation of dimethyl sulfide and methanethiol in anoxic freshwater sediments. Appl Environ Microbiol 63, 4741-4747.

Lyimo, T. J., Pol, A., Op den Camp, H. J. M. \& van der Drift, C. (1997). The role played by microorganisms in mangrove ecosystems with particular reference to methane and sulfide production. Proceedings of the CIDA/SAREC Workshop on Physiology \& Ecology of Mangrove Ecosystems, Zanzibar, Tanzania. CIDA/SAREC.

Lyimo, T. J., Pol, A., van der Drift, C. \& Op den Camp, H. J. M. (1998). Microbial ecology of a Tanzanian mangrove sediment: in situ and in vitro measurements with special emphasis on methane and sulfide production. In Proceedings of the 8th International Symposium on Microbial Ecology, Halifax, Canada, pp. 223.

Maestrojuán, G. M., Boone, J. E., Mah, R. A., Menaia, J. A. G. F., Sachs, M. S. \& Boone, D. R. (1992). Taxonomy and halotolerance of mesophilic Methanosarcina strain, assignment of strains to species, and synonymy of Methanosarcina mazei and Methanosarcina frisia. Int $J$ Syst Bacteriol 42, 561-567.

Mathrani, I. M., Boone, D. R., Mah, R. A., Fox, G. E. \& Liu, P. P. (1988). Methanohalophilus zhilinae sp. nov., an alkaliphilic, halophilic, methylotrophic methanogen. Int J Syst Bacteriol 38, 139-142.
Mohanraju, R., Rajagopal, B. S., Daniels, L. \& Natarajan, R. (1997). Isolation and characterization of a methanogenic bacterium from mangrove sediments. J Mar Biotechnol 5, 147-152.

Muller, V., Blaut, M. \& Gottschalk, G. (1986). Utilization of methanol plus hydrogen by Methanosarcina barkeri for methanogenesis and growth. Appl Environ Microbiol 52, 269-274.

Ni, S. \& Boone, D. R. (1991). Isolation and characterization of a dimethyl sulfide-degrading methanogen, Methanolobus siciliae HI350, from an oil well, characterization of $M$. siciliae $\mathrm{T} 4 / \mathrm{M}^{\mathrm{T}}$, and emendation of $M$. siciliae. Int J Syst Bacteriol 41, 410-416.

Ni, S. \& Boone, D. R. (1993). Catabolism of dimethylsulfide and methane thiol by methylotrophic methanogens. In Biogeochemistry of Global Change, pp. 796-810. Edited by R. S. Oremland. New York: Chapman \& Hall.

Ni, S., Woese, C. R., Aldrich, H. C. \& Boone, D. R. (1994). Transfer of Methanolobus siciliae to the genus Methanosarcina, naming it Methanosarcina siciliae, and emendation of the genus Methanosarcina. Int J Syst Bacteriol 44, 357-359.

Oremland, R. S. \& Boone, D. R. (1994). Methanolobus taylorii sp. nov., a new methylotrophic, estuarine methanogen. Int $J$ Syst Bacteriol 44, 573-575.

Oremland, R. S. \& Polcin, S. P. (1986). Methanogenesis and sulfate reduction: competitive and noncompetitive substrates in estuarine sediments. Appl Environ Microbiol 44, 1270-1276.

Oremland, R. S., Marsh, L. M. \& Polcin, S. (1982). Methane production and simultaneous sulfate reduction in anoxic salt marsh sediments. Nature 296, 143-145.

Paquet, L., Lafontaine, P. J., Saini, H. S., James, F. \& Hanson, A. D. (1995). Evidence in favor of the presence of 3-dimethylsulfoniopropionate in a large gamut of angiosperms. Can J Bot 73, 1889-1896.

Powell, G. E. (1983). Interpreting gas kinetics of batch cultures. Biotechnol Lett 5, 437-440.

Raskin, L., Stromley, J. M., Rittmann, B. E. \& Stahl, D. A. (1994). Group-specific 16S rRNA hybridization probes to describe natural communities of methanogens. Appl Environ Microbiol 60, 1232-1240.

Rouviere, P., Mandelco, L., Winker, S. \& Woese, C. R. (1992). A detailed phylogeny for the Methanomicrobiales. Syst Appl Microbiol 15, 363-371.

Springer, E., Sachs, M. S., Woese, C. R. \& Boone, D. R. (1995). Partial gene sequences for the A subunit of methyl-coenzyme $\mathbf{M}$ reductase ( $m c r 1)$ as a phylogenetic tool for the family Methanosarcinaceae. Int J Syst Bacteriol 45, 554-559.

Tallant, T. C. \& Krzycki, J. A. (1997). Methylthiol:coenzyme M methyltransferase from Methanosarcina barkeri, an enzyme of methanogenesis from dimethylsulfide and methylmercaptopropionate. J Bacteriol 179, 6902-6911.

Wassenaar, R. W., Daas, P. J. H., Geerts, W. J., Keltjens, J. T. \& van der Drift, C. (1996). Involvement of methyltransferase activating protein and methyltransferase 2 isoenzyme II in methylamine:coenzyme $\mathbf{M}$ methyltransferase reactions in Methanosarcina barkeri Fusaro. J Bacteriol 178, 6937-6944.

Widdel, F. \& Bak, F. (1992). Gram-negative mesophilic sulfatereducing bacteria. In The Prokaryotes, 2nd edn, pp. 3352-3378. Edited by A. Balows, H. G. Trüper, M. Dworkin, W. Harder \& K. H. Schleifer. New York: Springer. 